Scientia Agricola

http://dx.doi.org/10.1590/0103-9016-2014-0217

\title{
Model-predicted ammonia emission from two broiler houses with different rearing systems
}

\author{
Nilsa Duarte Silva Lima, Rodrigo Garófallo Garcia, Irenilza Alencar Nääs*, Fabiana Ribeiro Caldara, Roselaine Ponso
}

Federal University of Grande Dourados/College of Agrarian Sciences, Rod. Dourados Itahum, km 12, C.P. 533 - 79804 970 - Dourados, MS - Brazil.

*Corresponding author <irenilza@gmail.com>

Edited by: Carlos Eduardo Pellegrino Cerri

\begin{abstract}
Ammonia $\left(\mathrm{NH}_{3}\right)$ emissions from broiler production can affect human and animal health and may cause acidification and eutrophication of the surrounding environment. This study aimed to estimate ammonia emissions from broiler litter in two systems of forced ventilation, the tunnel ventilation (TV) and the dark house (DH). The experiment was carried out on eight commercial broiler houses, and the age of the birds (day, d), pH and litter temperature were recorded. Broilers were reared on built-up wood shaving litter using an average flock density of 14 bird $\mathrm{m}^{-2}$. Temperature and relative humidity inside the broiler houses were recorded in the morning during the grow-out period. A factorial experimental design was adopted, with two types of houses, four replicates and two flocks with two replicates each. A deterministic model was used to predict ammonia emissions using the litter $\mathrm{pH}$ and temperature, and the day of grow-out. The highest litter temperature and $\mathrm{pH}$ were found at $42 \mathrm{~d}$ of growth in both housing systems. Mean ambient air temperature and relative humidity did not differ in either system. Mean model predicted ammonia emission was higher in the $\mathrm{DH}$ rearing system $\left(5200 \mathrm{mg} \mathrm{NH}_{3} \mathrm{~m}^{-2} \mathrm{~h}^{-1}\right.$ at $42 \mathrm{~d}$ ) than in the TV system ( $2700 \mathrm{mg} \mathrm{NH}_{3} \mathrm{~m}^{-2} \mathrm{~h}^{-1}$ at $42 \mathrm{~d}$ ). TV presented the lowest mean litter temperature and $\mathrm{pH}$ at $42 \mathrm{~d}$ of growth. In the last week of the broilers' grow-out cycle, estimated ammonia emissions inside DH reached $5700 \mathrm{mg} \mathrm{m}^{-2} \mathrm{~h}^{-1}$ in one of the flocks. Ammonia emissions were higher inside $\mathrm{DH}$, and they did not differ between flocks. Assuming a broiler market weight in Brazil of close to $2 \mathrm{~kg}$, ammonia emissions were equivalent to $12 \mathrm{~g} \mathrm{NH}_{3}$ bird-marketed ${ }^{-1}$. Model-predicted ammonia emissions provided comprehensible estimations and might be used in abatement strategies for $\mathrm{NH}_{3}$ emission.

Keywords: noxious gases, environmental impact, dark house, poultry, tunnel ventilation
\end{abstract}

Received June 27, 2014

Accepted April 02, 2015 housings (Gates et al., 2008; Snoek et al., 2014). Full-scale in situ measurements are costly and time-consuming, and their accuracy might be compromised by variations in the final broiler market weight (Gates et al., 2008).

Field estimations of poultry $\mathrm{NH}_{3}$ emissions have already been calculated in some countries (Groot Koerkamp et al., 1998; Demmers et al., 1999; Guiziou and Béline, 2005; Pescatore et al., 2005; Wheeler et al., 2006; Gates et al., 2008; Harper et al., 2009; Calvet et al., 2011). Emissions per bird are suggested to be correlated with bird age and litter condition (Groot Koerkamp et al., 1998; Wheeler et al., 2006; Gates et al., 2008), but the results are highly variable (Wheeler et al., 2006; Casey et al., 2010). Mechanistic and deterministic algorithms have been used to estimate $\mathrm{NH}_{3}$ emissions from animal housing under particular circumstances (Bouwman et al., 1997; Miragliotta et al., 2004; Gates et al., 2005; Siefert and Scudlark, 2008; Casey et al., 2010). The estimation of ammonia shows high variability influencing the predictive emission models (Snoek et al., 2014), and found values have been adopted to define $\mathrm{NH}_{3}$ emission inventories in different regions and countries (Groot Koerkamp et al., 1998; Demmers et al., 1999; Wheeler et al., 2006; Gates et al., 2008; Harper et al., 2009; Harper et al., 2010; Calvet et al., 2011).

This study aimed to estimate $\mathrm{NH}_{3}$ emissions in two broiler houses during the grow-out cycle using a predictive model. 


\section{Materials and Methods}

\section{Birds, housing and husbandry}

The study was carried out in eight commercial broiler houses located at longitude $54^{\circ} 11^{\prime} 6^{\prime \prime} \mathrm{W}$ and latitude $23^{\circ} 28^{\prime} 26^{\prime \prime} \mathrm{S}$ from March to May, 2013. Birds from the Hubbard ${ }^{\circledast}$ genetic strain were reared in mixed flocks (male and female) for $42 \mathrm{~d}$ (market age). In the tunnel system (TV, Figure 1A), 25200 broilers were reared, and 31500 broilers were raised in the dark house system (DH, Figure 1B). The adopted average flock density was 14 bird $\mathrm{m}^{-2}$ in $\mathrm{TV}$ and $\mathrm{DH}$. The bedding in both houses was $10 \mathrm{~cm}$ of build-up wood shavings reused by the third time. The houses were east-west solar oriented.

Four houses had the TV system and four the DH system. TV houses $(12 \mathrm{~m}$ wide, $150 \mathrm{~m}$ long and $3.2 \mathrm{~m}$ high, and a floor area of $1800 \mathrm{~m}^{2}$ ) had forced ventilation, exhaust fans ( 11 with air flow of $450 \mathrm{~m}^{3} \mathrm{~s}^{-1}$ ), a high-pressure fogging system and the lateral areas were closed off with yellow polypropylene curtains. DH houses (15 $\mathrm{m}$ wide, $150 \mathrm{~m}$ long and $3.8 \mathrm{~m}$ high, and a floor area of $31500 \mathrm{~m}^{2}$ ) had forced ventilation; exhaust fans (12 with air flow of $580 \mathrm{~m}^{3} \mathrm{~s}^{-1}$ ), a high-pressure fogging system, and internal built walls painted with a black coating. In both houses the chick heating system used during day 1
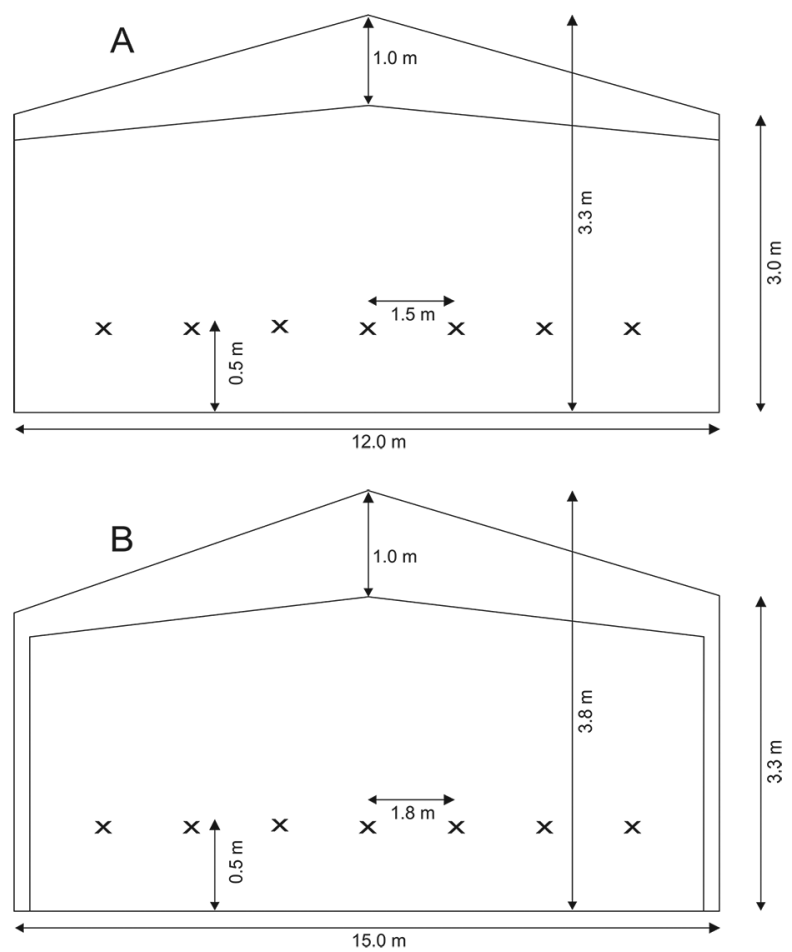

Figure 1 - Schematic dimensions of the tunnel ventilated commercial broiler houses (TV, A and DH, B). Each " $x$ " marks a location where dry bulb ambient temperature and air relative humidity were recorded. Samples of litter temperature and $\mathrm{pH}$ were collected on the place projecting this same location on the floor totaling 28 sampling points (7 in each quadrant). to 14 of the grow-out period consisted of a stove (burned wood) with the heat distributed through metallic tubes with sensors controlling the inlet air temperature. Light intensity inside the houses was set at $25 \mathrm{~lx}$ for the first weeks of grow-out (7-21 d), and at $5 \mathrm{~lx}$ for the remainder of the grow-out cycle (42 d) using automatic light control based sensors placed in the houses. The two systems had similar ventilation systems with the air inlet at one end, and the outlet at the opposite side. They differed in the reflectivity inside, as the inside walls in the $\mathrm{DH}$ houses were coated with black paint.

Ambient air temperature was controlled automatically using the association of the evaporative cooling system and negative pressure ventilation. The air flow was programmed to decrease air temperature from $32{ }^{\circ} \mathrm{C}$ on the first day to $27^{\circ} \mathrm{C}$ after two weeks, and finally to 24 ${ }^{\circ} \mathrm{C}$ during the end of the grow-out phase.

\section{Data recording}

Air temperature $\left(\mathrm{AT},{ }^{\circ} \mathrm{C}\right)$ and relative humidity $(\mathrm{RH}, \%)$ were measured in the morning (10h00) in the houses using sensors equally distributed over 28 points during the grow-out cycle (Figure 2). Litter $\mathrm{pH}$ and temperature $\left(\mathrm{LT}^{\circ}{ }^{\circ} \mathrm{C}\right)$ were recorded at the same time using a portable meter. Data recording in areas nearby or below drinkers and feeders were avoided. The age of birds was computed in days (d).

Ammonia emissions were assessed in the area near the air outlet of the houses using the capsule method suggested by Jeppsson (1999) at 21, 35 and $40 \mathrm{~d}$ of the grow-out cycle. The methodology allows for estimating the amount of ammonia emissions in a particular area of the litter. The closed cubic capsule had an air inlet using a PVC tube $(\Phi 0.075 \mathrm{~m})$ and inside it a small fan $(12 \mathrm{~V}, 60 \mathrm{~mA})$ was placed to promote homogeneity in the capsule's inside air. The air outlet had a small exhaust fan (maximum flow of $90 \mathrm{~m}^{3} \mathrm{~h}^{-1}$ ) adjusted with a dimmer. The samples of ammonia concentration were taken at a height of $1 \mathrm{~m}$ at a point in the PVC tube, after allowing the capsule to be under continuous flow for 20 min in the same place. Ammonia concentrations were measured using a gas pump. Ammonia emissions $(\varepsilon$, $\mathrm{mg} \mathrm{m}^{-2} \mathrm{~h}^{-1}$ ) were estimated using Equation 1 (Jeppsson, 1999).

$\varepsilon=\left(\mathrm{C}_{\text {caps }}-\mathrm{C}_{2}\right) \sigma \varphi$

in which $\mathrm{C}_{\text {caps }}=$ ammonia concentration inside the capsule $(\mathrm{ppm}), \mathrm{C}_{2}=$ ammonia concentration at $2 \mathrm{~m}$ of height (ppm), $\sigma=$ the corrected density of ammonia at the capsule outlet $\left(0.765 \mathrm{~kg} \mathrm{~m}^{-2}\right)$, and $\varphi=$ air flow $\left(\mathrm{m}^{3}\right.$ $\left.\mathrm{m}^{-2} \mathrm{~h}^{-1}\right)$.

\section{Model-prediction of ammonia emission}

Mean values of recorded variables were calculated, and they were used as input to the software developed using the deterministic algorithm described in Equation 2 (Miragliotta et al., 2004). 


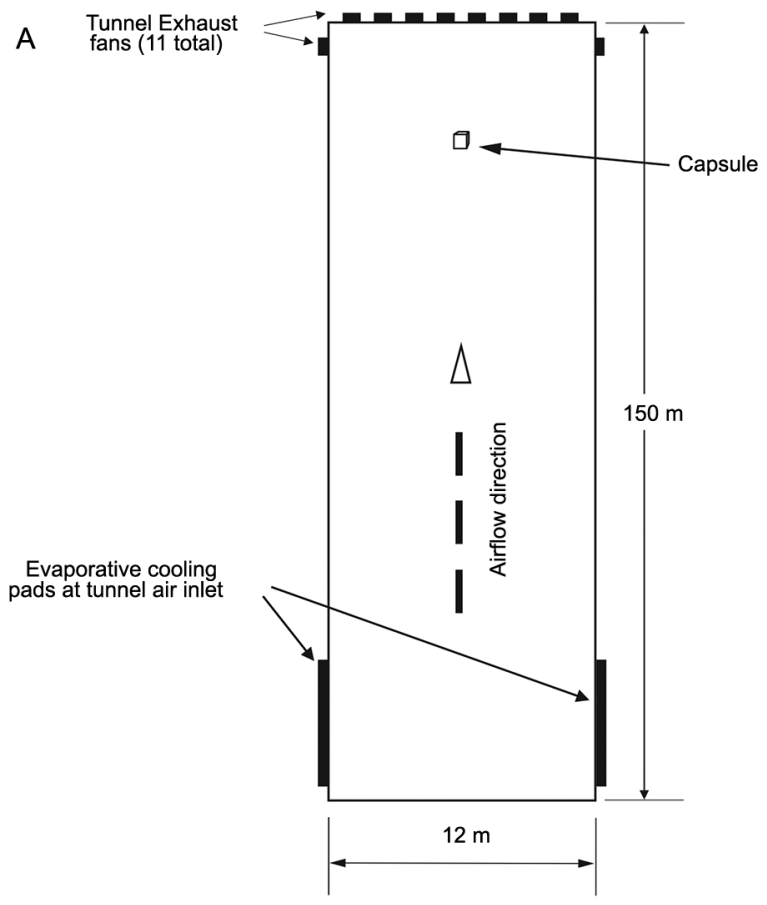

\section{Statistical analysis}

The experimental design was completely randomized in a $2 \times 4$ factorial design (TV and $\mathrm{DH}_{\text {; }}$ ages 7,21 , 35 and $42 \mathrm{~d}$ of growth) with four replicates per treatment, totaling 32 experimental units. The KolmogorovSmirnov test was used to verify the hypothesis of normality for all variables, using a $95 \%$ confidence limit. Analysis of variance was used to compare means using the Tukey and the F-test at a $95 \%$ confidence level. For the model-predicted ammonia emission, a $2 \times 2$ factorial design was adopted, considering the type of the broiler house (TV and DH) and two replications for the number of flocks. All statistical analysis was carried out according to Wheater and Cook (2000) using ASSISTAT ${ }^{\circledast}$ software (Assistat-Statistical Attendance Software, version 7.6).

\section{Results and Discussion}

The Kolmogorov-Smirnov test showed a normal distribution of the data. An effect of the type of house (factor, F1) or age of birds (F2) was found ( $p>0.05)$ in the ambient air temperature and relative humidity only at $35 \mathrm{~d}(p=0.1$; Table 1$)$. Environmental data inside the houses did not differ, indicating that the chosen variables should not be the cause of possible variation in the estimation of $\mathrm{NH}_{3}$ emissions. Ambient air temperature is considered a primary factor in regulating the chemical processes involved in ammonia emissions (Wheeler et al., 2006; Sommer et al., 2006; Casey et al., 2010). Previous studies showed that the distribution uniformity of environmental features may affect broiler weight gain (Miragliotta et al., 2006; Lima et al., 2011).

TV houses had lower mean values of LT and $\mathrm{pH}$ (30.0 ${ }^{\circ} \mathrm{C}$ and 8.4, respectively) than $\mathrm{DH}$ houses $\left(33.3^{\circ} \mathrm{C}\right.$ and 8.6, respectively), Table 2 . The factor age of broilers presented the highest mean amount at the end of the grow-out cycle ( $42 \mathrm{~d}$ ). The distribution uniformity of environmental features may affect broiler weight gain (Miragliotta et al., 2006; Lima et al., 2011). The mean pH values of the two houses (TV and $\mathrm{DH}$ ) showed a slight difference from the $7 \mathrm{~d}(8.2)$ to $42 \mathrm{~d}$ of growth. In the present study litter $\mathrm{pH}$ was 8.9 in the $\mathrm{DH}$ houses and 8.8 in the TV houses at $42 \mathrm{~d}$ of grow-out.

Table 1 - Analysis of variance using factors applied to litter temperature (LT), litter pH, ambient air temperature (AT) and relative humidity $(\mathrm{RH})$.

Figure 2 - Schematic plan view of the tunnel ventilated broiler houses TV (A) and DH (B) used in the study.

$\mathrm{E}=\exp (-6.502+0.302 \mathrm{~d}+0.122 \mathrm{LT}+0.614 \mathrm{pH}-$ $\left.0.004 \mathrm{~d}^{2}\right)$

in which $\mathrm{E}=$ model-predicted ammonia emission $/ \mathrm{mg}$ $\left.\mathrm{m}^{-2} \mathrm{~h}^{-1}\right), \mathrm{d}=$ day of grow out, $\mathrm{LT}=$ mean litter temperature $\left({ }^{\circ} \mathrm{C}\right)$, and $\mathrm{pH}=$ litter $\mathrm{pH}$.

\begin{tabular}{lcccl}
\hline Factor & $\mathrm{F}(\mathrm{LT})$ & $\mathrm{F}(\mathrm{pH})$ & $\mathrm{F}(\mathrm{AT})$ & $\mathrm{F}(\mathrm{RH})$ \\
\hline House (F1) & $42.82^{* *}$ & $7.53^{*}$ & $0.29 \mathrm{~ns}$ & $3.60 \mathrm{~ns}$ \\
Age of birds (F2) & $12.44^{* *}$ & $18.46^{* *}$ & $140.24^{* *}$ & $6.34^{*}$ \\
Int. F1 $\times \mathrm{F} 2$ & $1.35 \mathrm{~ns}$ & $0.56 \mathrm{~ns}$ & $2.30 \mathrm{~ns}$ & $3.11^{*}$ \\
\hline Treatment & $12.03^{* *}$ & $9.23^{* *}$ & $61.13^{* *}$ & $4.56^{* *}$ \\
\hline Standard deviation & 2.73 & 0.31 & 2.99 & 8.27 \\
\hline Coefficient of variatio (\%) & 5 & 2 & 3 & 9 \\
\hline * significant at $1 \%$ of confidence $(p \leq 0.01) \mathrm{F}$ - value; ${ }^{*}$ significant at $5 \%$ of \\
confidence $(0.01 \leq p<0.05) \mathrm{F}-$ value; $\mathrm{ns}=$ non-significant $(p>0.05)$.
\end{tabular}


An important aspect of ammonia emission is the litter characteristics (Groot Koerkamp et al., 1998; Gates et al., 2008). Excreta accumulation on litter increases the litter $\mathrm{pH}$ and leads to a rise in $\mathrm{NH}_{3}$ concentrations inside broiler houses (Wheeler et al., 2006). The higher the litter $\mathrm{pH}$, the lower the conversion of $\mathrm{NH}_{3}$ (volatile) into $\mathrm{NH}_{4}^{+}$(nonvolatile). Consequently, high ammonia volatilization in built-up litter without proper management is usual (Kristensen et al., 2000). The dark house presented higher litter temperature than the tunnel ventilation system and the ammonia emission in the DH should be greater than in the TV system (Table 2). Broiler housing presents a broad range of $\mathrm{NH}_{3}$ emission rates depending on the flock harvest day and the ambient temperature during the grow-out period (Guiziou and Béline, 2005; Wheeler et al., 2006).

$\mathrm{NH}_{3}$ emissions increased with bird age (Figure 3), which corroborates previous studies (Wheeler et al., 2006; Calvet et al., 2011; Lin et al., 2012). Ammonia emissions increased with broiler growth due to the consequent excreta build-up (Ngwabie et al., 2010, Calvet et al., 2011). There is a strong association between emissions, bird age, and litter condition (Gates et al., 2008; Casey et al., 2010). Broilers were reared on built-up litter, which is known to increase $\mathrm{NH}_{3}$ emissions. Gates et al. (2008) and Lima et al. (2011) assessed the ammonia emissions in tunnel ventila-

Table 2 - Mean values of litter temperature (LT) and $\mathrm{pH}$, ambient air temperature (AT) and relative humidity (RH) inside the aviaries during the total grow out time.

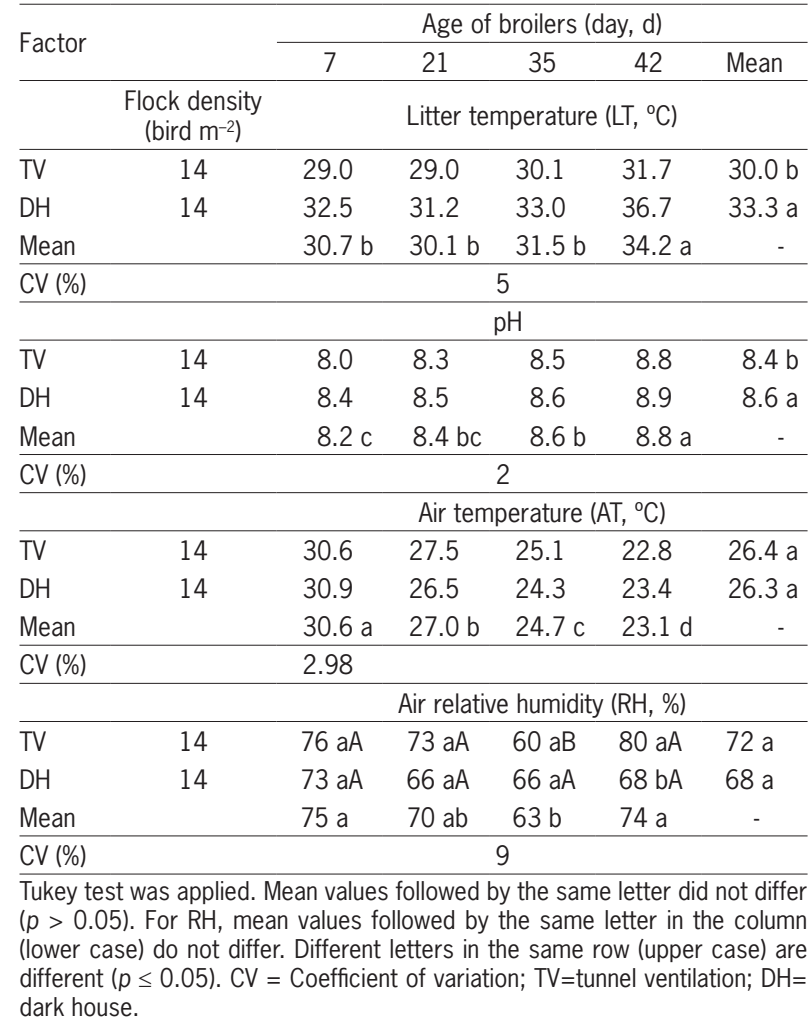

tion houses and found lower rates of $\mathrm{NH}_{3}$ emission in new bedding than in those with built-up litter. However, the renewal of bedding in each flock is not used by farmers as it may lead to an increase in production costs.

Mean values of ambient AT did not differ $(p>$ $0.05)$ and varied according to broiler requirements in each grow-out period (Table 2). The values were $26.4{ }^{\circ} \mathrm{C}$ in TV and $26.3{ }^{\circ} \mathrm{C}$ in $\mathrm{DH}$. Mean values of $\mathrm{RH}$ did not differ between houses; however, an interaction between the "house" and "age of broilers" factors was identified at 35 and $42 \mathrm{~d}$ of growth. The change in $\mathrm{pH}$ depends on the age of the birds, and it may be attributed to the effect of litter temperature, ambient temperature and density of birds (Pescatore et al., 2005; Menegali et al., 2012). The $\mathrm{pH}$ of litter also influences the release of ammonia, which is maximized at levels of $\mathrm{pH}$ above 7.0. The difference between the temperature and litter $\mathrm{pH}$ at different ages provided a growing impact on the degradation reaction of nitrogen compounds in poultry litter and tended to be alkaline. The increase in temperature and $\mathrm{pH}$ of the litter provided greater microbial activity and the formation of noxious gases (Calvet et al., 2011). Thus, the quantity and quality of litter affect the ability of $\mathrm{NH}_{3}$ emissions from broiler housing (Toghyani et al., 2010).

The provision of minimum ventilation in the most uniform way is essential to ensuring good air quality control inside broiler housing. The small air exchange, high humidity, temperature and $\mathrm{pH}$, and type of litter management may induce greenhouse gas emissions (Menegali et al., 2012).

\section{Model-predicted ammonia emissions}

Mean ammonia emission amounts measured inside the TV using the capsule were similar for both houses studied at the first stage of the grow-out cycle (Figure 4). However, results varied during the broiler grow-out phase, $725 \mathrm{mg} \mathrm{NH}_{3} \mathrm{~m}^{-2} \mathrm{~h}^{-1}$ at $21 \mathrm{~d}, 2200 \mathrm{mg} \mathrm{NH}_{3} \mathrm{~m}^{-2}$ $\mathrm{h}^{-1}$ at $35 \mathrm{~d}$, and $2700 \mathrm{mg} \mathrm{NH}_{3} \mathrm{~m}^{-2} \mathrm{~h}^{-1}$ at $42 \mathrm{~d}$ of grow-out.

No effect was found for the studied factors at 7 d of growth (Table 3) from the model-predicted value. The house (F1) affected ammonia emission at $21 \mathrm{~d}$. At $35 \mathrm{~d}$, there was an interaction $(p \leq 0.05)$ between the factors (F1 and F2), meaning that the type of broiler house and the number of flocks were interacting. The average

Table 3 - Analysis of variance for model-predicting ammonia emissions in two different broiler houses $\left(\mathrm{mg} \mathrm{m}^{-2} \mathrm{~h}^{-1}\right)$ during two flocks and at four grow out days.

\begin{tabular}{|c|c|c|c|c|}
\hline Factor & $\mathrm{F}(7 \mathrm{~d})$ & $F(21 d)$ & $F(35 d)$ & $F(42 d)$ \\
\hline Type of aviary (F1) & $7.69 \mathrm{~ns}$ & $12.79^{*}$ & $33.67 * *$ & $30.03^{* *}$ \\
\hline Number of flocks (F2) & $0.13 \mathrm{~ns}$ & $0.00 \mathrm{~ns}$ & $19.06^{*}$ & $4.93 \mathrm{~ns}$ \\
\hline Int. F1 × F2 & $1.29 \mathrm{~ns}$ & $0.28 \mathrm{~ns}$ & $9.98^{*}$ & $0.03 \mathrm{~ns}$ \\
\hline Treatment & $3.04 \mathrm{~ns}$ & $4.36 \mathrm{~ns}$ & 20.90 ** & $11.66^{*}$ \\
\hline Standard deviation & 26 & 193 & 877 & 1408 \\
\hline Coefficient of variation (\%) & 36 & 22 & 31 & 36 \\
\hline
\end{tabular}



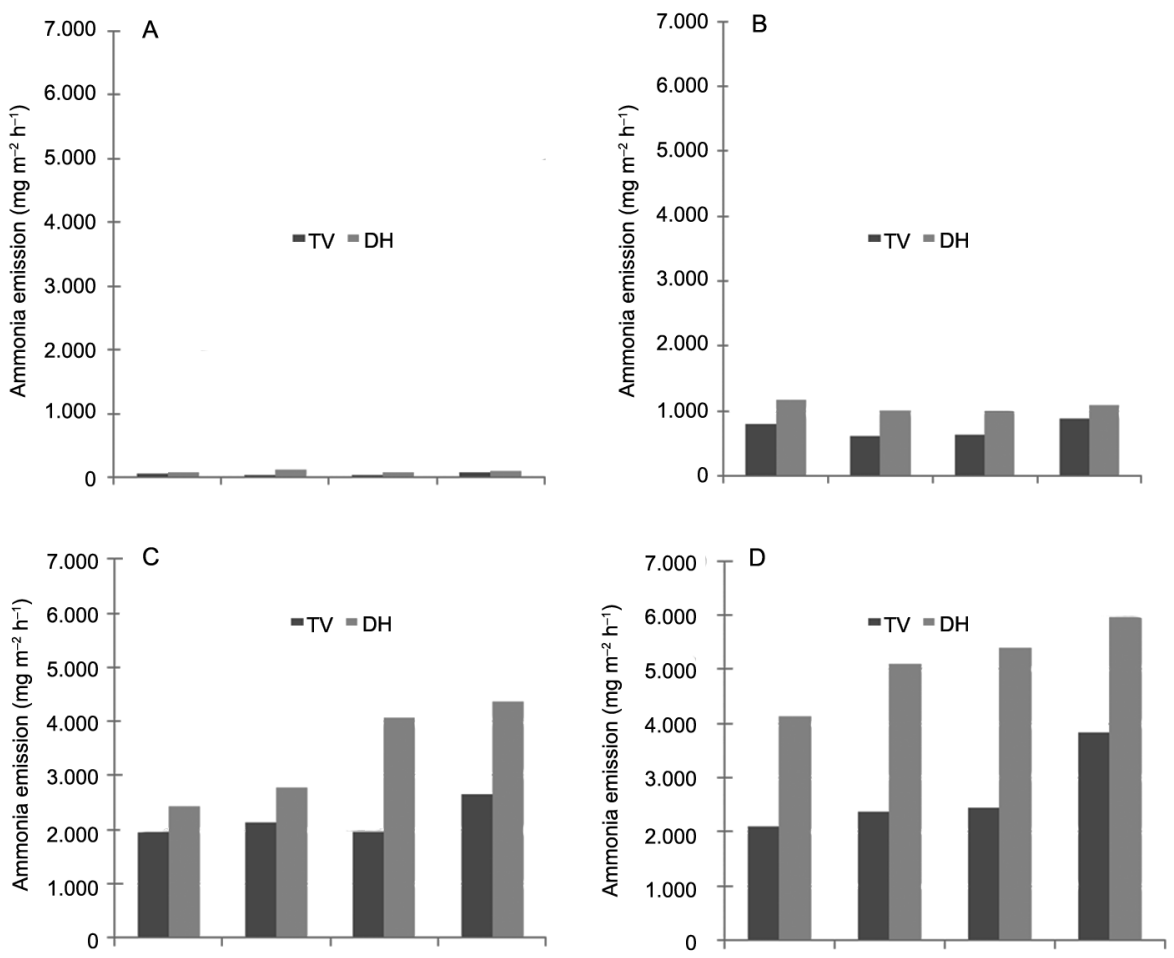

Figure 3 - Model-predicted ammonia emissions from two broiler houses (Tunnel ventilation, TV and dark house, DH) at four grow-out phases, 7 days (A), 21 days (B), 35 days (C) and 42 days (D).

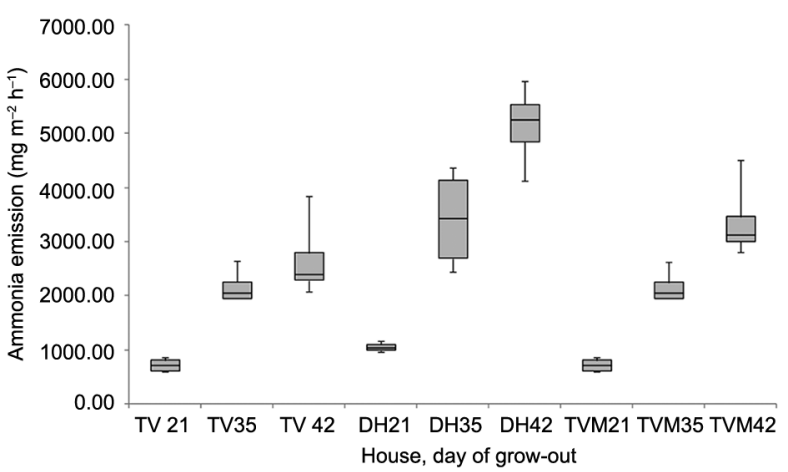

Figure 4 - Box plot of model-predicted ammonia emissions from two broiler houses (tunnel ventilation, TV, dark house, DH) and the measured values using the capsule method (TVM) at 21, 35 days and 42 days of the grow-out phase.

model-predicted value of ammonia emission in $\mathrm{DH}$ in the second flock was $5200 \mathrm{mg} \mathrm{m}^{-2} \mathrm{~h}^{-1}$, and also on TV with lower emission (2200 $\mathrm{mg} \mathrm{m}^{-2} \mathrm{~h}^{-1}$; Table 4).

Siefert and Scudlark (2008) studied ammonia emissions from tunnel system houses and found values of $2700 \mathrm{mg} \mathrm{NH}_{3}$ bird $^{-1}$, equivalent to $2.7 \mathrm{~g} \mathrm{NH}_{3}$ bird $^{-1}$. Results obtained in the present experiment, at $35 \mathrm{~d}$ were lower than that with an average emission (in TV and $\mathrm{DH}$ ) of $\sim 4000 \mathrm{mg} \mathrm{NH}_{3} \mathrm{~m}^{-2} \mathrm{~h}^{-1}$ (12 $\mathrm{g} \mathrm{NH}_{3}$ bird $\left.{ }^{-1}\right)$. Gates et al. (2008) found values of ammonia emission near 20 $\mathrm{g} \mathrm{NH}_{3}$ bird ${ }^{-1}$, practically double the results found in the present study. Harper et al. (2010) evaluated the weekly average emission during the growth cycle of the birds, which resulted in a total of $4 \mathrm{~kg} \mathrm{NH}$ per tunnel ventilation house during the summer. The result is similar to that found in the present study, on average $5 \mathrm{~kg}$ of $\mathrm{NH}_{3}$ per flock in tunnel ventilation. Redwine et al. (2002) found that $\mathrm{NH}_{3}$ emission rates in broiler production varied from 38 to $2105 \mathrm{mg} \mathrm{NH}_{3} \mathrm{~h}^{-1}$. Despite the high variations between the results cited, the lowest value in the current literature is similar to that obtained in the present study, when considering the house with a total area of $1800 \mathrm{~m}^{2}$. Assuming a market bird weight of $2 \mathrm{~kg}$ the highest ammonia emission value found was $12 \mathrm{~g} \mathrm{NH}_{3}$ bird-marketed ${ }^{-1}$.

The highest model-predicted ammonia emission occurred on the $21^{\text {st }} \mathrm{d}$ of growth in $\mathrm{DH} / 1000 \mathrm{mg} \mathrm{NH}$ $\left.\mathrm{m}^{-2} \mathrm{~h}^{-1}\right)$. On the $35^{\text {th }} \mathrm{d}$, there was an interaction between the "house" and "number of flocks" factors, and the largest model-predicted value of ammonia emission was for $\mathrm{DH}\left(4200 \mathrm{mg} \mathrm{m}^{-2} \mathrm{~h}^{-1}\right)$ during flock 2, different from flock 1 (2600 $\left.\mathrm{mg} \mathrm{m}^{-2} \mathrm{~h}^{-1}\right)$. On the last day of growth (market age, $42 \mathrm{~d}$ ) considering the type of house, the highest model-predicted mean value of ammonia emission in DH (5700 $\left.\mathrm{mg} \mathrm{m}^{-2} \mathrm{~h}^{-1}\right)$ was found. Modelpredicted $\mathrm{NH}_{3}$ emissions increased along the grow-out cycle, arising from an increase in excreta deposition on litter (Figure 3). The ammonia emission found using the model-predicted ammonia, and those measured inside 
Table 4 - Mean model-predicting ammonia emission $\left(\mathrm{mg} \mathrm{NH}_{3} \mathrm{~m}^{-2}\right.$ $\left.\mathrm{h}^{-1}\right)$ in two broiler houses and during two flocks and at four phases of the growth cycle $(7,21,35$ and 42 days).

\begin{tabular}{|c|c|c|c|c|c|}
\hline \multirow{3}{*}{ Factor } & \multicolumn{5}{|c|}{ Number of flocks } \\
\hline & 1 & 2 & Mean & $\begin{array}{l}\text { Standard } \\
\text { deviation }\end{array}$ & $\begin{array}{l}\text { Coefficient of } \\
\text { variation (\%) }\end{array}$ \\
\hline & \multicolumn{5}{|c|}{ 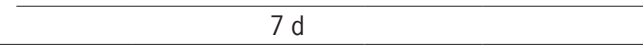 } \\
\hline TV & 40 & 60 & $50 a$ & 17 & 34 \\
\hline DH & 100 & 90 & 95 a & 20 & 17 \\
\hline Mean & $70 \mathrm{a}$ & $70 \mathrm{a}$ & - & 36 & 25 \\
\hline $\begin{array}{l}\text { Standard } \\
\text { deviation }\end{array}$ & 31 & 18 & - & - & - \\
\hline \multirow[t]{2}{*}{$\begin{array}{l}\text { Coefficient of } \\
\text { variation (\%) }\end{array}$} & 46 & 25 & - & - & - \\
\hline & \multicolumn{5}{|c|}{$21 \mathrm{~d}$} \\
\hline TV & 700 & 750 & $725 b$ & 112 & 15 \\
\hline $\mathrm{DH}$ & 1100 & 1000 & $1050 \mathrm{a}$ & 78 & 7 \\
\hline Mean & $900 \mathrm{a}$ & $900 \mathrm{a}$ & - & 192 & 21 \\
\hline $\begin{array}{l}\text { Standard } \\
\text { deviation }\end{array}$ & 212 & 173 & - & - & - \\
\hline \multirow[t]{2}{*}{$\begin{array}{l}\text { Coefficient of } \\
\text { variation (\%) }\end{array}$} & 23 & 19 & - & - & - \\
\hline & \multicolumn{5}{|c|}{$35 d$} \\
\hline TV & $2050 \mathrm{aA}$ & $2300 \mathrm{bA}$ & $2200 \mathrm{~b}$ & 287 & 13 \\
\hline $\mathrm{DH}$ & $2600 \mathrm{aB}$ & $4200 \mathrm{aA}$ & $3400 \mathrm{a}$ & 829 & 24 \\
\hline Mean & $2330 \mathrm{~b}$ & $3250 \mathrm{a}$ & - & 877 & 31 \\
\hline $\begin{array}{l}\text { Standard } \\
\text { deviation }\end{array}$ & 317 & 1005 & - & - & - \\
\hline \multirow[t]{2}{*}{$\begin{array}{l}\text { Coefficient of } \\
\text { variation (\%) }\end{array}$} & 13 & 30 & - & - & - \\
\hline & \multicolumn{5}{|c|}{$42 \mathrm{~d}$} \\
\hline TV & 2200 & 3100 & $2700 \mathrm{~b}$ & 686 & 25 \\
\hline $\mathrm{DH}$ & 4600 & 5700 & $5200 \mathrm{a}$ & 670 & 13 \\
\hline Mean & $3400 \mathrm{a}$ & $4400 \mathrm{a}$ & - & 1408 & 36 \\
\hline $\begin{array}{l}\text { Standard } \\
\text { deviation }\end{array}$ & 1255 & 1387 & - & - & - \\
\hline $\begin{array}{l}\text { Coefficient of } \\
\text { variation (\%) }\end{array}$ & 36 & 31 & - & - & - \\
\hline
\end{tabular}

the houses were similar on the grow-out days 21,35 and 42 in TV. Nevertheless, the values differed from those found in the DH on days 35 and 42 (Figure 4).

The emission rate of ammonia tends to be relatively stable in the first weeks of growth, rising by the third week of life. This increase coincides with the growth period of the birds, and the feed intake is higher than in other phases of the cycle. These emission factors such as concentration of excreta in litter temperature, $\mathrm{pH}$ and rate of ventilation may be associated (Harper et al., 2010).

Groot Koerkamp et al. (1998) found values of ammonia emissions in European countries near $11000 \mathrm{mg}$ $\mathrm{m}^{-2} \mathrm{~h}^{-1}$. The highest value found in the present study was $\sim 6000 \mathrm{mg} \mathrm{m}^{-2} \mathrm{~h}^{-1}$ in the DH house (Table 4), which is nearly half of the values found previously. Studying $\mathrm{NH}_{3}$ emissions from new and built-up litter Gates et al.
(2008) found that broilers raised on built-up litter emit $\sim 25 \mathrm{~g} \mathrm{NH}_{3}$ bird-marketed ${ }^{-1}$. Our highest findings of $\mathrm{NH}_{3}$ emissions (with market weight in Brazil near $2 \mathrm{~kg}$ ) in built-up litter was equivalent to $12 \mathrm{~g} \mathrm{NH}_{3}$ bird-market$\mathrm{ed}^{-1}$, which is lower than the results for broilers reared in new bedding. Wheeler et al. (2006) found a mean value of $17 \mathrm{~g} \mathrm{NH}_{3}$ bird-marketed ${ }^{-1}$, which was similar to the results found in the present study. Values found here were similar to those found by Calvet et al. (2011) in southern Europe $\left(24 \mathrm{~g} \mathrm{NH}_{3}\right.$ bird-marketed $\left.{ }^{-1}\right)$.

According to Liu et al. (2011) ventilation rate changes inside the housing may be the cause of different results in ammonia emission estimation. Liu et al. (2011) showed that when air velocity increased to a predetermined level $\left(\geq 1.6 \mathrm{~m} \mathrm{~s}^{-1}\right)$, emission flux increases. The loss of nitrogen and water from the litter is no longer negligible, which results in reduced measurements of emission fluxes. The differences in air flow inside the houses might be the reason for significant differences in the ammonia emission results found in current literature (Groot Koerkamp et al., 1998; Wheeler et al., 2006; Gates et al., 2008; Harper et al., 2009; Calvet et al., 2011).

Predicted levels of $\mathrm{NH}_{3}$ emissions from the model had a sharp increase after the $35^{\text {th }}$ day of grow-out in the $\mathrm{DH}$, when compared to the predictive value of $\mathrm{TV}$, and the measured quantity using the capsule (TVM, Figure 2). The $\mathrm{NH}_{3}$ emissions were similar to those estimated in the TV houses but differed substantially from those in the DH house after the $35^{\text {th }} \mathrm{d}$ of the grow-out cycle.

Whereas the methods applied to this study can be used for estimating ammonia emission trends, the information presented should not be used for making regulatory determinations. However, the model provided comprehensible estimation and might be used as $\mathrm{NH}_{3}$ emission abatement strategies. The estimated ammonia emission was higher in the dark house than in the tunnel ventilation system. The amount of ammonia increased gradually throughout the grow-out cycle in both types of houses, and the highest mean value was attributed to the dark house system. The results from the predictive model showed a similar level of ammonia emissions in the tunnel ventilated house, but the level differed from the dark house starting during the broiler grow-out stage.

\section{Acknowledgment}

The authors wish to thank the Coordination for the Improvement of Higher Level Personnel (CAPES) for supporting this research.

\section{References}

Beusen, A.H.W.; Bouwman, A.F.; Heuberger, P.S.C.; Drecht, G. van; Hoek, K.W. van der. 2008. Bottom-up uncertainty estimates of global ammonia emissions from global agricultural production systems. Atmospheric Environment 42: 6067-6077. 
Bouwman, A.F.; Lee, D.S.; Asman, W.A.H.; Dentener, F.J.; Hoek, K.W. van der; Oliver, G.J. 1997. A global high-resolution emission inventory for ammonia. Global Biogeochemical Cycles 11: 561-587.

Calvet, S.; Cambra-López, M.; Estellés, F.; Torres, A.G. 2011. Characterization of gas emissions from a Mediterranean broiler farm. Poultry Science 90: 534-542.

Casey, K.D.; Gates, R.S.; Shores, R.C.; Thomas, D.; Harris, D.B. 2010. Ammonia emissions from a U.S. broiler housecomparison of concurrent measurements using three different technologies. Journal of the Air \& Waste Management Association 60: 939-48

Demmers, T.G.M.; Burgess, L.R.; Short, J.L.; Phillips, V.R.; Clark, J.A.; Wathes, C.M. 1999. Ammonia emissions from two mechanically ventilated UK livestock buildings. Atmospheric Environment 33: 217-227.

Gates, R.S.; Casey, K.D.; Wheeler, E.F.; Xin, H.; Pescatore, A.J. 2008. US broiler housing ammonia emissions inventory. Atmospheric Environment 42: 3342-3350.

Gates, R.S.; Xin, H.; Casey, K.D.; Liang, Y.; Wheeler, E.F. 2005. Method for measuring ammonia emissions from poultry houses. Journal of Applied Poultry Research 14: 622-634.

Groot Koerkamp, P.W.G.; Metz, J.H.M.; Uenk, G.H.; Phillips, V.R.; Holden, M.R.; Sneath, R.W.; Short, J.L.; White, R.P.P.; Hartung, J.; Seedorf, J.; Schröder, M.; Linkert, K.H.; Pedersen, S.; Takai, H.; Johnsen, J.O.; Wathes, C.M. 1998. Concentrations and emissions of ammonia in livestock buildings in Northern Europe Journal of Agricultural Engineering Research 70: 79-95.

Guiziou, F; Béline, F. 2005. In situ measurement of ammonia and greenhouse gas emissions from broiler houses in France. Bioresource Technology 96: 203-207.

Harper, L.A.; Flesch, T.K.; Wilson, J.D. 2010. Ammonia emissions from broiler production in the San Joaquin Valley. Poultry Science 89: 1802-814.

Harper, L.A.; Flesch, T.K.; Powell, J.M.; Coblentz, W.K.; Jokela, W.E.; Martin, N.P. 2009. Ammonia emissions from dairy production in Wisconsin. Journal of Dairy Science 92: 23262337.

Jeppsson, K.H. 1999. Volatilization of ammonia in deep litter systems with different bedding materials for young cattle. Journal of Agricultural Engineering Research 7: 49-57.

Kristensen, H.H.; Burgess, L.R.; Demmers, T.G.M.; Wathes, C.M. 2000. The preferences of laying hens for different concentrations of atmospheric ammonia. Applied Animal Behaviour Science 68: 307-318.

Lima, K.A.O.; Moura, D.J.; Carvalho, T.M.R.; Bueno, L.G.F.; Vercellino, R.A. 2011. Ammonia emissions in tunnel-ventilated broiler houses. Brazilian Journal of Poultry Science 13: 265-270.

Lin, X.J.; Cortus, E.L.; Zhang, R.; Jiang, S.; Heber, A.J. 2012. Air emissions from broiler houses in California. Transactions of the ASABE 55: 1895-1908.

Liu, Z.; Wang-Li, L.; Beasley, D.B.; Shah, S.B. 2011. Validation and uncertainty analysis of an ammonia emission model for broiler litter. Transactions of the ASABE 54: 1051-1057.
Menegali, I.; Tinôco, I.F.F.; Zolnier, S.; Carvalho, C.C.S.; Guimarães, M.C.C. 2012. Influence of different systems of minimum ventilation on air quality in broiler houses. Engenharia Agrícola 32: 1024-1033.

Miragliotta, M.Y.; Nääs, I.A.; Manzione, R. L.; Nascimento, F.F. 2006. Spatial analysis of stress conditions inside broiler house under tunnel ventilation. Scientia Agricola 63: 426-432.

Miragliotta, M.Y.; Nääs, I.A.; Murayama, M.C.; Moura, D.J. 2004. Software for estimating ammonia emission in broilers housing. Revista Brasileira de Agroinformática 6: $79-89$ (in Portuguese, with abstract in English).

Ndegwa, P.M.; Hristov, A.N.; Arogo, J.; Sheffield, R.E. 2008. A review of ammonia emission mitigation techniques for concentrated animal feeding operations. Biosystems Engineering 100: 453-469.

Ngwabie, N.M.; Jeppsson, K.H.; Gustafsson, G.; Nimmermark, S. 2010. Influence of environmental factors and the addition of wood shavings on ammonia and odour emissions from fresh livestock manure. Agricultural Engineering International: CIGR Journal 12: 68-80.

Pescatore, A.J.; Casey, K.D.; Gates, R.S. 2005. Ammonia emissions from broiler houses. Journal of Applied Poultry Research 14: 635-637.

Redwine, J.S.; Lacey, R.E.; Mukhtar, S.; Carey, J.B. 2002. Concentration and emissions of ammonia and particulate matter in tunnel-ventilated broiler houses under summer conditions in Texas. Transactions of the ASAE 45: 1101-1109.

Siefert, R.L.; Scudlark, J.R. 2008. Determination of ammonia emission rates from a tunnel ventilated chicken house using passive samplers and a Gaussian dispersion model. Journal of Atmospheric Chemistry 59: 99-115.

Snoek, D.J.W.; Stigter, J.D.; Oginkc, N.W.M.; Groot Koerkamp, P.W.G. 2014. Sensitivity analysis of mechanistic models for estimating ammonia emission from dairy cow urine puddles. Biosystems Engineering 121: 12-24.

Sommer, S.G.; Zhang, G.Q.; Bannink, A.; Chadwick, D.; Misselbrook, T.; Harison, R.; Hutchings, N.J.; Menzi, H.; Monteny, G.J.; Ni, J.Q.; Oenema, O.; Webb, J. 2006. Algorithms determining ammonia emission from buildings housing cattle and pigs and from manure stores. Advances in Agronomy 89: 261-335.

Toghyani, M.; Gheisari, A.; Modaresi, M.; Tabeidian, S.A.; Toghyani, M. 2010. Effect of different litter material on performance and behavior of broiler chickens. Applied Animal Behaviour Science 122: 48-52.

UNFCCC. 1997. Kyoto Protocol to the United Nations Framework. Convention on Climate Change. Available at: http://unfccc. int/2860.php [Accessed Mar 30, 2014].

Wheater, C.P.; Cook, P.A. 2000. Using Statistics to Understand the Environment. Routledge, New York, NY, USA.

Wheeler, E.F.; Casey, K.D.; Gates, R.; Xin, H.; Zajaczkowski, J.L.; Topper, P.A.; Liang, Y.; Pescatore, A.J. 2006. Ammonia emissions from twelve U.S. broiler chicken houses. Transactions of the ASABE 49: 1495-1512. 